\title{
The Effect of Interaction between The Form of Formative Assessment and Learning Autonomy on Learning by Controlling Mathematical Logical Intelligence
}

\author{
Mahayukti Gst Ayu ${ }^{1}$, Candiasa I.M ${ }^{2}$, Dantes $\mathrm{N}^{3}$, Marhaeni A.A.I.N ${ }^{4}$ \\ ${ }^{1}$ Mathematics Education Department, \\ ${ }^{2}$ Educational Sciences Post-Graduate Study Program \\ ${ }^{3,4}$ Post-Graduate Study Program \\ UNDIKSHA \\ Singaraja, Indonesia \\ gustiayumahayukti@undiksha.ac.id ${ }^{1}$
}

\begin{abstract}
This study was aimed at investigating the effect of interaction between the form of formative assessment and learning autonomy on learning achievement after controlling mathematical logical intelligence. The forms of formative assessment used in this study consisted of portfolio assessment and essay assessment. This study was conducted at Mathematics Education Department of Universitas Pendidikan Ganesha in Integral Calculus course using $2 \times 2$ treatment by level and involving 88 students who were selected by random. The data were analyzed by two way covariates analysis after mathematical logical intelligence was controlled. The result showed that there was an effect of interaction between the form of formative assessment and learning autonomy on learning achievement after logical mathematical intelligence was controlled. The students with a high learning autonomy were more suited to the learning process with portfolio assessment, while on the students with a low learning autonomy was more suited to the learning process with essay assessment.
\end{abstract}

Keywords : form of formative assesement; Integral Calculus learning achievement

\section{INTRODUCTION}

In the S1 Mathematics Education Department Curriculum, it is clearly stated that Integral Calculus is one of the compulsory courses for the students of Mathematics Education Department of the Faculty of Mathematics and Science, Undiksha which is offered in the second semester. The expected competence is for the students to understand Integral Calculus concepts meaningfully by using Differential Calculus concepts. This shows that Integral Calculus should make the students not only know and learn procedures about the Integral Calculus concepts by heart, but it also should make them understand the concepts and their relationship with other concepts.

To be able to reach this, the lecturer should make the students learn the course meaningfully by preparing a semester program plan that requires him/her to perform process assessment in order the students can be assessed comprehensively. Then, the students should also be ready to follow the course. The readiness here means being able to understand the Integral Calculus course materials meaningfully. A good mastery is required very much from the students, since the concepts contained in this course are the foundation and prerequisite for other courses.

However, Integral Calculus instruction is still a problem for the students, as what is revealed by Astuti in [1] that some causes of the problem are that the students' low mastery of Integral Calculus basic concepts, and the instructional process and assessment process applied are still conventional processes. This view is also confirmed by Mahayukti in [2] and [3] who stated that the low learning achievement in Calculus course was caused by the fact that : 1) the students still use a learning pattern like the one at high school 2) they are weak in Calculus concepts. Based on the experience in teaching this course and the result of an interview with the students it can be stated that the assessment used so far has been made based only on some tasks which sometimes have not been followed up, the middle test and the final test have been in the form of essay given after the learning process. Essay assessment has some weaknesses since it does not measure students' competence comprehensively and tends to cover limited materials.

Assessment which only refers to certain cognitive aspects does not represent the real knowledge of the students will only be procedural in nature. According to Javanmard in [4] problems which arise as the effect of an inaccurate assessment can demotivate the individual to learn leading to a low learning achievement. This reality is the gap in Integral Calculus instruction between the expectation and the reality.

This formative assessment is not only in the form of test, it can also be in the form of a summary or portfolio collected by the students. Anderson and Krathwol in [5] point out that 
formative assessment gives information to the teacher and the students concerning the materials which are being discussed.

Assessment forms intended in this study are portfolio assessment and essay assessment. Kaino in [6] said that portfolio assessment gives opportunity to the lecturer to think about what the student will do and why they should do it. In this way the lecturer can assess actions that have been taken now and the result expected, this reflective practice is aimed at helping the lecturer to think about the decision and experience that they have got. This statement also supported by Stiggins in [7] who stated that Portfolio assessment has an outstanding benefit compared to other written assessments. Since the students are involved in self assessment from time to time Dantes in [8] also said that portfolio assessment is also a comprehensive assessment approach since it can cover cognitive, affective and psychomotor domains and can facilitate interests and progresses of the students individually.

The results of research previously which are related to portfolio come from Hosseini and Gabhanci in [9] who show that portfolio assessment has a significant effect in enhancing students' reading experience and motivation, similar to this finding is the finding of a research done by Dewi, Dantes \& Marhaeni in [10] in which it is shown that the use of portfolio assessment can increase writing ability in English after verbal ability is controlled.

Beside assessment factor, Hargis in [11] said that there is the internal factor in the student which influences a students' learning achievement, and this factor is learning autonomy. Learning autonomy aspect is the students' internal factor which also has an effect on his or her attainment of learning achievement. Boekaerts \& Zedner in [12] and Camahalan in [13] find that there is a very significant positive correlation between students' mathematics academic achievement and his/her learning autonomy.

According to Gredler in [14], learning autonomy was first introduced by Bandura in the social cognitive theory which states that social, cognitive, and behavioral factors play an important role in learning process. While Zimmerman in [15] defines learning autonomy as the process that has occurred because of the effect of thinking, feeling, strategy and one's own behavior which orient one to the goal.

Thus, literally, learning autonomy can be defined as the condition in which in the effort to get knowledge, an individual does not depend on other people. The students learns autonomously and this does not mean that he/she learns alone. The role of the lecturer is still required. The instruction has to be designed to make the students active, the lecturer's domain should be lessened in the classroom and it should be taken over by his/her role as facilitator and motivator.

Autonomy in learning according to Zimmerman \& Martines-Pons in [16] and Boekaerts, Pintrich \& Zeidner in [12] there is an open process which needs cyclical activities in three dimensions: forethought, volitional control, and self reflection. This is also supported by Zimmerman in [17] who said that the students who have learning autonomy feel and act to achieve the instructional goal. This is not much different from Pintrich's view in [18] that there are four dimensions in forming the students' learning autonomy, i.e., forethought (planning, activation), monitoring (control), reaction, and reflection.

In relation to the characteristics of a higher level of mathematics materials, including Integral Calculus, theorems almost form the core of the mathematical discussion, so does the proving of theorems. The proving of a theorem (this also applies in answering essay mathematical problems) is a rigorous procedure. Suparta in [19] said that it means that the truth of every statement has to be accounted for based on logical-mathematical rules. This process requires students' hard work. The details of the evidence of a theorem can be different but have to follow rigorous and correct stages of proving according to logic and mathematics. So an act of proving something stresses hard work, honesty, and discipline very much. Hard work and honesty are closely related to the characteristics of portfolio assessment.

A question related to the characteristics and the implementation of learning autonomy is why learning autonomy needs to be considered in the individual who learns mathematics, especially Integral Calculus. The answer is related to the nature and vision in mathematics as a subject of study. Sumarmo in [20] stated that mathematics has a variety of meanings, depending on who uses it. One of its definitions of mathematics is a discipline which stresses the importance of logical and axiomatic reasoning, containing inductive process, mathematical model, analogy and generalization. The implication of such a nature of mathematics is then mathematics is oriented toward developing among other things: (1) mathematical thinking ability; (2) mathematical disposition or habit, and a high quality learning attitude. The learning habit and attitude are reflected among other things in the characteristics of learning autonomy. While Gardner in [21] said that another factor which contributes to the students' learning achievement, both directly and indirectly is the students' logical mathematical intelligence. Logical mathematical intelligence is the ability that is related to the use of numbers and logic effectively.

Logical mathematic intelligence is a combination of mathematical ability and logical ability so that the students can solve a problem logically. Logical mathematical intelligence is needed in learning mathematics which puts the first priority to mathematical ability and logic. According to Campbell in [22], logical mathematical ability involves many components: mathematical calculation, logical thinking, problem solving, deductive and inductive consideration, and sharpness of patterns and relations. That statement also supported by Suparta in [19] who said that Integral Calculus which studies about integral theorems, calculus basic theorems, and unnatural integral application really needs logical mathematical intelligence, since one of the objects in mathematical education is theorem. The result of a research done by Yalmanci \& Gozum in [23], Safranj in [24] and Winastri, Suparta \& Sariyasa in [25] shows that logical mathematical intelligence contributes to the ability to solve problems and students' learning achievement.

Based on the background of the problems that have been stated, the problem in this study was whether there is any 
effect of interaction between the form of formative assessment and the students' learning autonomy on their learning Integral Calculus learning achievement after controlling their mathematical intelligence.

\section{RESEARCH METHODS}

This study was conducted in the Even Semester in the academic year of 2015/2016 at Mathematics Education Department of the Faculty of Mathematics and Science of Undiksha. The population consisted of all students of Mathematics Education Department who learned Integral Calculus. The population was distributed into four classes with relatively homogeneous characteristics. A random sampling resulted in class $\mathrm{B}$ and class $\mathrm{C}$ as experiment group and class $\mathrm{A}$ and class D as control group.

Each group was divided into top group (having a high autonomy) and bottom group (having a low autonomy), by allotting 33\% for top group and low group. This method supported by Gall, Gall \& Borg in [26]. Then the members of the sample of each cells were selected randomly with the same number ( 22 ) so that the total of the sample was 88 .

Lawshe test in [27] involves 8 experts to determine content validity of the instrument before being tried out empirically. To measure learning achievement, an Integral Calculus learning achievement test was used. The result of the empirical try-out showed that the ten items used were valid with the reliability coefficient of 0.87 . The result of empirical testing of learning autonomy questionnaire showed that 37 items were valid with the reliability coefficient of 0.89 . Meanwhile, the result of the empirical try-out test showed that 5 items failed for mathematical intelligence test and 40 items were valid with the reliability coefficient of 0.85

\section{RESUlTS AND DisCUSSION}

\section{A. The Testing of Analysis Perequisite}

The testing of analysis of perquisite used SPSS 20.00 consisting of normality testing of data distribution, homogeneity testing, linearity testing, significance testing and the parallelism of the regression lines. And all of the tests met the prerequisite so that it could be continued with hypothesis testing.

\section{B. Hypothesis Testing Units}

The results of the study which were analyzed with SPSS program are presented in Table 1 .

TABLE I. CORRECTED AVERAGE OF INTEGRAL CALCULUS LEARNING ACHIEVEMENT FORMED BY FORMS OF FORMATIVE ASSESSMENT AND LEARNING AUTNOMY FACTORS

\begin{tabular}{|l|c|c|c|}
\hline \multirow{2}{*}{$\begin{array}{c}\text { Learning } \\
\text { Autonomy }\end{array}$} & \multicolumn{2}{|c|}{ Table Column Head } & \multirow{2}{*}{ Total } \\
\cline { 2 - 3 } & Portfolio & Essay & \\
\hline High & 80.56 & 71.56 & 76.06 \\
\hline Low & 72.54 & 75.85 & 76.06 \\
\hline Total & 76.55 & 73.70 & \\
\hline
\end{tabular}

TABLE II. UNIVARIATE GLM FORM BY FACTORS A AND B

\begin{tabular}{|l|r|c|c|c|c|c|}
\hline Source & $\begin{array}{c}\text { Type III } \\
\text { Sum of } \\
\text { Squares }\end{array}$ & df & $\begin{array}{c}\text { Mean } \\
\text { Square }\end{array}$ & F & Sig. & $\begin{array}{c}\text { Partial } \\
\text { Eta } \\
\text { Square } \\
\text { d }\end{array}$ \\
\hline $\begin{array}{l}\text { Corrected } \\
\text { Model }\end{array}$ & $1834,468^{\mathrm{a}}$ & 4 & 458,617 & 29,619 & 0,000 & 0,588 \\
\hline Intercept & 3272,383 & 1 & 3272,383 & $\begin{array}{c}211,34 \\
2\end{array}$ & 0,000 & 0,718 \\
\hline $\mathrm{X}$ & 586,979 & 1 & 586,979 & 37,909 & 0,000 & 0,314 \\
\hline $\mathrm{A}$ & 177,440 & 1 & 177,440 & 11,460 & 0,001 & 0,121 \\
\hline $\mathrm{B}$ & 76,741 & 1 & 76,741 & 4,956 & 0,029 & 0,056 \\
\hline A $*$ B & 824,767 & 1 & 824,767 & 53,266 & 0,000 & 0,391 \\
\hline Error & 1285,157 & 83 & 15,484 & & & \\
\hline Total & 499771,000 & 88 & & & & \\
\hline $\begin{array}{l}\text { Corrected } \\
\text { Total }\end{array}$ & 3119,625 & 87 & & & & \\
\hline
\end{tabular}

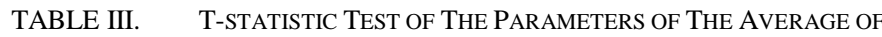
INTEGRAL CALCULUS LEARNING ACHIEVEMENT (Y) OF ALL LEVELS OF FORMS OF FORMATIVE ASSESSMENT (A), FOR EVERY LEVEL OF LEARNING ACHIEVEMENT (B) BY CONTROLLING MATHEMATICAL LOGICAL INTELLIGENCE $(\mathrm{X})$

\begin{tabular}{|l|c|c|c|c|}
\hline \multicolumn{1}{|c|}{ Parameter } & B & Std. Error & T & Sig \\
\hline Intercept & 53.60 & 3.74 & 14.33 & 0.00 \\
\hline $\mathrm{X}$ & 0.80 & 0.13 & 6.16 & 0.00 \\
\hline$[\mathrm{B}=1]$ & $-4,28$ & 1.19 & -3.60 & 0.00 \\
\hline$[\mathrm{B}=2]$ & $0^{\mathrm{a}}$ & $\cdot$ & $\cdot$ & $\cdot$ \\
\hline$[\mathrm{A}=1] *[\mathrm{~B}=1]$ & 8.99 & 1.19 & 7.55 & 0.00 \\
\hline$[\mathrm{A}=1] *[\mathrm{~B}=2]$ & -3.31 & 1.19 & -2.79 & 0.01 \\
\hline$[\mathrm{A}=2] *[\mathrm{~B}=1]$ & $0^{\mathrm{a}}$ & $\cdot$ & $\cdot$ &. \\
\hline$[\mathrm{A}=2] *[\mathrm{~B}=2]$ & $0^{\mathrm{a}}$ & $\cdot$ & $\cdot$ & $\cdot$ \\
\hline
\end{tabular}

Hypothesis 1

$$
\begin{aligned}
& H_{0}:(A x B)_{i j}=0, \text { for all i's and j's } \\
& H_{1}(A x B)_{i j} \neq 0, \text { for all i's and j's }
\end{aligned}
$$

In Table 2, line $(\mathrm{A} * \mathrm{~B})$ the $\mathrm{F}_{\text {obs }}$ obtained was 53.27 at sig. lower than 0.05 , which means $\mathrm{H}$ was rejected. Hence, there was an effect of the interaction between the form of formative assessment and learning autonomy on learning achievement in Integral Calculus, after controlling logical mathematical intelligence. Hence, the test could be continued with t-test.

Then, the simple effect hypothesis test could be done as follows.

Hypothesis 2

$$
\begin{aligned}
& H_{0}: \mu^{*} A_{1} B_{1}=\mu^{*} A_{2} B_{1} \\
& H_{0}: \mu^{*} A_{1} B_{1}>\mu^{*} A_{2} B_{1}
\end{aligned}
$$


In Table 3, line $[(\mathrm{A}=1) *(\mathrm{~B}=1)]$ the $\mathrm{t}_{\mathrm{obs}}$ value was 7.55 at sig. $<=0.05$, so that $\mathrm{H} 0$ was rejected. Then, Table 1 shows that in the group of students with a high learning autonomy, the corrected average of learning achievement in Integral Calculus of the students who learned through the process of instruction with portfolio assessment was 80. 56, higher than that of those who learned through a process with essay assessment (71. 56).

Hence, in the group of students with a high learning autonomy, the learning achievement in Integral Calculus of the students who learned through the process of instruction with portfolio assessment was significantly higher than that of those who learned through the process instruction with essay assessment, after controlling logical mathematical intelligence.

Hypothesis 3

$$
\begin{aligned}
& H_{0}: \mu^{*} A_{1} B_{2}=\mu^{*} A_{2} B_{2} \\
& H_{1}: \mu^{*} A_{1} B_{2}<\mu^{*} A_{2} B_{2}
\end{aligned}
$$

In Table 3 , line $[(\mathrm{A}=1) *(\mathrm{~B}=2)]$ the $\mathrm{t}_{\mathrm{obs}}=-2.79$ and $\left|t_{\text {obs. }}\right|=2.79$ at sig. $<0.05$, so that $\mathrm{H} 0$ was rejected. Then, from Table 1, it is apparent that in the group of students with a low learning autonomy, the corrected average of learning achievement in Integral Calculus of the students who learned through the process of instruction with portfolio assessment was 72.54 , lower than that of those who learned through the process of instruction with essay assessment (75. 85).

Hence, in the group of students with a low learning autonomy, the learning achievement in Integral Calculus of the students who learned in the process of instruction with portfolio assessment was lower than that of those who learned through the process of learning, after controlling logical mathematical intelligence.

Furthermore, in addition to the results of hypothesis testing that has been described, from the analysis of the students' responses after the test finished it can be seen that the students who learned in the process of instruction with portfolio assessment had a better ability in solving C4 and C5 level items than those of the students in the control group, this can be seen from the percentage of correct answers of the problems which reached $70 \%$, while in the control group it only reached $40 \%$. Besides, a feedback to the students' work had stimulated $80 \%$ of the students to do their tasks seriously. Suparta in [19] said that the effect of logical mathematical intelligence in this case has to be controlled since it is the ability that is related to the effective use of numbers and logic and this intelligence is very important since it helps in developing an individual's thinking skill and logic, and is related to mathematics, especially Integral Calculus. This statement was also confirmed by Safranj in [24] who states that the students who learned a subject that was oriented toward logical mathematical intelligence obtained a better learning achievement than the conventional group.

Suherman in [28] stated that the process of learning with portfolio assessment conforms to the learning theory with the constructivist perspective, since the assessment in mathematics instruction occurs as an on -going assessment. In addition, Herman in [29] said that the application of portfolio assessment in teaching helps the students in solving more difficult and complex problems, since mathematics cannot be separated from theorems which are interrelated and abstract. Cakan,et al in [30] shows that the group who used portfolio had a better learning achievement than that of those who used portfolio, their attitude was also positive toward science. This was confirmed by Gunes, et al in [31] who shows that the application of portfolio assessment gave a positive effect on the students' success and decreased the level of anxiety as prospective teachers. Thus, to understand the concepts of Integral Calculus well, there has to be an on-going assessment. It means that to master high level mathematics, the students have to master the basic concepts well. Since mathematics has a hierarchical characteristic, it suits the on-going portfolio assessment very well and the students should be involved in giving the assessment of their works through self-assessment.

In addition, the students have the opportunities at least twice to do the tasks given, if portfolio assessment is used in teaching, when there is an error in a concept it can be corrected soon and the students' retention of the concept will become stronger, as put forward by Rose and Nicholl in [32] who states that the more frequent an individual can see, hear, write or do something, the easier it is for him/her to learn.

The result of the hypothesis testing is supported by the theory that there are two important things that should be considered in the process of teaching. First, what material is taught and how it is taught. In other words, the competence to be developed in the students has to be developed by considering the characteristics of the competences that the students have got and the characteristics of the students. Since Integral Calculus has very abstract materials which are related to each other like a spiral since it is a discipline which does not only contain concepts, formulas, or principles, but also processes of how the concepts or principles are obtained, the students need an extra effort to master the basic concepts well to understand and master the next material. This, certainly, needs autonomy from the part of the students, since learning autonomy can remedy the thinking process, and influence the learning process and learning achievement. Hiemstra in [33] states that an individual with a high level of learning autonomy has a high level of confidence about his or her ability and a high initiative in performing the tasks (learning), this is like what is put forward by Zimmerman in [15] that the student with learning autonomy has autonomy in thinking, feeling and does something to reach the learning goal. Secondly, how to do an assessment or access the students' learning development. In this context, assessment used has to suit the characteristics of the learning achievement indicators. Thus, there is a need for a suitable assessment, and to know when the appropriate time to access the students' learning development is. The most important thing is how to follow up the result obtained through the assessment to improve learning. Ahmed in [34] finds out that change in emotion and learning correlates positively with mathematics learning achievement. Similarly, Mulyaningsih in [35] also shows that learning autonomy has a significantly positive 
effect on the students' learning autonomy. It means that the higher learning autonomy the higher the learning achievement. This is explained in a more precise terms by Olaoye in [36] that a students' learning autonomy has a significant correlation with her or his mathematics learning achievement.

The characteristics of portfolio assessment goes very well with a high learning autonomy, thus portfolio assessment is more effective in increasing the learning achievement of the students with a high learning autonomy. Lubis in [37] stated that the students with a high autonomy are more able and more confident to organize information by themselves and always do an analysis of the information obtained by themselves compared to those with a low autonomy if they are given an essay assessment which tends to make the students less creative.

So far in Integral Calculus course the lecturer tends to use essay assessment and the students follow the given rules in completing it. Since the concept to be used to do the assessment is already clear, this causes the students not to have an opportunity to do his or her self- assessment that is related to the works that they have done, they tend to use only the principles and concepts that have been taught to solve the problem so that they do not know the errors that they make, and the errors will be repeated over and again. The students become less able to relate a principle or concept and this has an impact on the students' learning achievement

The implementation of the two formative types of assessment will create different conditions and environments. This has an impact on the students' concept understanding. The condition of teaching using an appropriate assessment will make the teaching become optimal. This agrees with Aiken's statement in [38] that the advantage of using portfolio assessment is that it can measure the students' abilities to organize, to relate their thinking patterns well which cannot be easily found out from other assessments.

Based on the empirical findings and the relevant results of studies it can be concluded that there is an effect of interaction between the form of formative assessment on learning achievement in the Integral Calculus, after controlling logical mathematical intelligence.

\section{CONCLUSION}

Based on the result of hypotheses testing, then the finding from this study is that there is an effect of interaction between the form of formative assessment and learning autonomy on the students' Integral Calculus learning achievement, after controlling logical mathematical intelligence. In the group of students with a high learning autonomy, the students'

Integral Calculus learning achievement who learned through the process of instruction with portfolio assessment is higher than that of those who learned through the process of learning with essay assessment.

With reference to the finding of this study, it is suggested that the lecturers in Mathematics Education Department to make portfolio assessment one of the alternative assessments to be implemented in research on other courses and can choose a form of assessment that suits the students' characteristics. This findings of such studies are expected to complement this research finding at Mathematics Education Department of the Faculty of Mathematics and Science of Undiksha.

\section{REFERENCES}

[1] Astuti, E. P. 2008.” Identifikasi Kesalahan Menyelesaikan Kalkulus Mahasiswa Prodi Pendidikan Matematika Universitas Muhammadiyah Purworejo.” Jurnal Universitas Muhammadiyah Purworejo.

[2] Mahayukti, G.A. 2014. "Pengembangan Perangkat Pembelajaran Berbasis Masalah Berbantuan Pertanyaan-Pertanyaan Pembimbing untuk Meningkatkan Kualitas Perkuliahan Kalkulus." Prosiding dalam Seminar Nasional Riset Inovatif ke-2 yang diselenggarakan oleh Lemlit Undiksha. Unpublished.

[3] Mahayukti, G.A. 2016. "Pengembangan Perangkat Pembelajaran Berbasis Masalah Berbantuan Software Matematika dengan Asesmen Autentik untuk Meningkatkan Efektifitas Perkuliahan Kalkulus Integral dan Kemandirian Belajar Mahasiswa" Prosiding dalam Seminar Nasional Riset Inovatif ke-4 yang diselenggarakan oleh LP2M Undiksha. Unpublished.

[4] Y. Javanmard and H. Faharani, "Investigating Using Portfolio Assessment and Learning English Language in Qom Secondary Schools." Global Journal of Human Social Science, 2012, 12(12): 5260.

[5] L.W. Anderson and Krathwohl, A Taxonomy For Learning Teaching and Assessing, A Revision of Blomm's Taxonomy of Educational Objectives. New York: Adison Weasley Longman, 2011.

[6] Kaino, L.M. 2014. "Asesment of Teahcing Mathematics Use Protofolio,” Mediterranean. Journal of Social Science, 5(15). (On line) (Accessed on the $6^{\text {th }}$ of November 2014).

[7] R. J. Stiggins, Student-Centered Classsroom Assessment. New York: Macmillan College Publishing Company, 1994

[8] N. Dantes, Landasan Pendidikan; Tinjauan dari Dimensi Makropedagogis. Yogyakarta: Graha Ilmu, 2014.

[9] H. Hosseini and Z. Ghabanchi. "The Effect of Portfolio Assessment on EFL Learners' Reading Comprehension and Motivation, English Language Teaching." 7(5). Published by Canadian Center of Science and Education 110, 2014.

[10] T. Ni. K. Dewi, N. Dantes, and A.A.I.N. Marhaeni. Pengaruh Implementasi Asesmen Portofolio terhadap Kemampuan Menulis dalam Bahasa Inggris dengan Kovariabel Kemampuan Verbal pada Siswa Kelas XI SMAN 1 Banjarangkan. e-Journal Program Pascasarjana Undiksha Program Studi Penelitian dan Evaluasi Pendidikan, 4: 1-9. , 2014

[11] J. Hargis. "The Self Regulated Learner Advantage: Learning Science on the Internet", 2000. Accessed on the 30th December 2014.

[12] M. Boekaerts, P. Pintrich, and M. Zeinider. "Hanbook of Self Regulation". San Diego: Academic Press, 2000.

[13] F.M.G. Camahalan, "Effects of Self Regulated Learning on Mathematics Achievement of Selected Southeast Asian Children". Journal of Instructional Psychology, 2000. 33 (3): 194-205.

[14] M. E.B. Gredler, Belajar dan Pembelajaran (Translated by Munandir). Jakarta: Rajawali Press, 1991.

[15] B. J. Zimmerman, "Becoming a Self Regulated Learner: An Overview." Theory Into Practice, 2002. 41 (2): 64-70.

[16] B, J. Zimmerman and M. Martines-Pons, "Students' Differences in Self-Regulated Learning: Relating Grade, Sex, and Giftedness to Self Efficacy and Strategy Use.” Journal of Education Psychology, 2001. 82 (1).

[17] B, J. Zimmerman, "Self-Regulated Learning and Academic Achievement: An Overview. Educational Psychologist", 1990. 25(1), 3-17. New York: Lawrence Erlbaum Associates, Inc. 
[18] M. Pintrich, P. Boekaerts and M. Zedner, "Hanbook of Self Regulation”. San Diego: Academic Press, 2000.

[19] I N. Suparta, "Kontribusi Pendidian Matematika Dalam Pengembangan Nilai Kemanusiaan". Read in Scientific Oration in an Introduction of Professor Office at Mathematics Education Department of Faculty of Mathemattics and Science of Ganesha Uniersity of Education in 2014.

[20] Sumarno. 2010. "Kemandirian Belajar: Apa, Mengapa Dan Bagaimana Dikembangkan Pada Peserta Didik." Tersedia pada: www. http//: kemandirian-belajar-mat-des-06-new pdf (Diakses 5 Februari 2016).

[21] H. Gardner, "Multiple Intelligences". Translated by Alexander Sindoro. Batam: Interaksa. 2003.

[22] L. Campbell, et. al, "Metode Praktis Pembelajaran Berbasis Multiple Intelligences". Depok: Intuisi Press, 2006.

[23] S.G. Yalmanci and A.I. Gozum, "The Effect of Multiple Intelligence Theory Based Teaching on Students' Achievement and Retention of Knowledge (Example of Enzymes Subyect)." International Journal on New Trends in Education and Their Implications, 2013. 4(4):27-36.

[24] J. Safranj, "Logical/Mathematical Intelligence in Teaching English as a Second Language." Procedia-Social and Behavioral Sciences, 2016. 232.

[25] N.K.Winastri, I.N. Suparta and Sariyasa. "Pengaruh Model pembelajaran Pemecahan Masalah Berorientasi Masalah Matematika Terbuka terhadap Kemampuan pemecahan Masalah Ditinjau dari Kecerdasan Logis Matematis Siswa Kelads X SMA Negeri 2 Denpasar". e-Journal Program Pascasarjana Universitas Pendidikan Ganesha Program Studi Penelitian dan Evaluasi Pendidikan (Volume 5 Nomor 1, 2016).

[26] M. Gall, J.P. Gall and W.R. Borg, "Educational Research". Seventh Edition. Boston, New York: Pearson Education, Inc.

[27] C.H. Lawshe, "A Quantitative Approach to Content Validity." Personal Psychology, 1975. 28: 563-575

[28] E. Suherman, "Assesment Portofolio" http://www.nationalforum.com/Electronic\%20Journal\%20Volumes/Th omas, \%20ConnPortfolio\%20Assessment\%20A\%20Guide\%20For\%20 Teachers\%20And\%20Administrator.pdf. EDUCARE: Jurnal
Pendidikan dan Budaya FPMIPA Universitas Pendidikan Indonesia. 2011.

[29] Herman, T. "Asesmen Portofolio Dalam Pembelajaran Matematika." http\\192.168.8.203।upi/DirektorilD-

FMIPAIFAK.PEND.MATEMATIKA DAN IPA/TATANG HERMAN\Artikellartikel 21.doc (Diakses 9 Oktober 2015).

[30] M. Cakan, G. Mihladiz, and B.G. Taskin, How Portfolio Use Affects Student's learning and Their Attitudes toward 6th Grade Science Lesson. International Online Journal of Educational Science, 2010. Vol.2 No.2: 362-377.

[31] M. H. Gunes, S. Demir, and M. Balaban, "The Effect of Portfolio Assessment Application On Academic Achievement and Test Anxiety in Teaching Animal Tissue". Necatibey Faculty of Education Electronic Journal of Science and Mathematics Education, 2015. Vol. 9 Issue 1: 1-22.

[32] Rose, C. \& Nicholl, Malcolm J. Accelerated Learning for The 21 Century (New York: Delacorte Press, 1997), h. 142.

[33] R. Hiemstra, "Self-directed learning, In T Husen \& T N Postlethwaite (Eds)", The International Encyclopedia of education (second edition). Oxford: Pergamon Press, Reprinted here by Permission, 1994.

[34] W. Ahmed, et al. "Emotions, Self- Regulated Learning, and Achievement in Mathematics: A Growth Curve Analysis." Journal of Educational Psychological Association, 2012.105 (1): 150-161.

[35] I.E. Mulyaningsih, "Pengaruh Interaksi sosial Keluarga, Motivasi dan Kemandirian Belajar Terhadap Prestasi Belajar." Jurnal Pendidikan dan Kebudayaan, 2014. 20 (4).

[36] A. A. Olaoye, "Effect of Self-Regulated Learning (SLR) and Conventional Strategies on Students' Performance in Mathematics." British Journal of Science, 2012. 4(1).

[37] S. Lubis, Hasruddin \& Mahmud, "Efektivitas Penggunanan Portofolio pada Perkuliahan Mikrobiologi terhadap Kemandirian dan Hasil Belajar Mahasiswa." E-Journal: Jurnal Pendidikan Biologi, Unimed. 6(1). December Edition. 2016.

[38] L. R. Aiken. "Psychological Testing and Assessment". Boston: Allyn and Bacon, Inc, 1988. 